\title{
PRELIMINARY PHYTOCHEMICAL ANALYSIS AND ANTIMICROBIAL ACTIVITY ETHANOLIC EXTRACTS OF DRIED FRUITS OF SOLANUM TORVUM (FAMILY-SOLANACEAE)
}

\author{
LAWRENCE KALITA ${ }^{*}$, BISWAJIT DASH ${ }^{1}$, UTTAM BORAH ${ }^{1}$, JUMAN DEKA¹, SUVAKANTA DASH ${ }^{1}$
}

Girijananda Chowdhury Institute of Pharmaceutical Science, Azara, Guwahati 781017

Email: lawrncekalita45@gmail.com

Received: 02 Jan 2017, Revised and Accepted: 31 Apr 2017

\section{ABSTRACT}

Objective: To study the antimicrobial activity ethanolic extracts of dried fruits of Solanumtorvum (family-solanaceae) along with preliminary phytochemical analysis.

Methods: The ethanolic extract of dried fruits of the herb Solanumtorvum (family-solanaceae) were prepared and analyzed for phytochemical constituents using standard methods. The antimicrobial activity of the plant extracts were examined against 2 bacterial strains among one is gram positive and other is gram negative and 2 fungus using agar well diffusion method.

Results: The present experiment shows the phytochemical analysis, antimicrobial activity of the ethanolic extract of dried fruits of the plant Solanumtorvum (family-solanaceae). Various phytochemical analysis revealed the presence of alkaloids, saponin, flavonoids, carbohydrates, glycosides, Steroids, proteins and amino acids and tannins. All the extracts of the plant showed antimicrobial activity against most of the test organisms.

Conclusion: It can be concluded ethanolic extract of whole aerial parts of the Solanumtorvum (family-solanaceae) contain the high presence of phytochemicals. This extract was found to possess promising antimicrobial activity when compared with the standards.

Keywords: Antimicrobial, Zone of Inhibition, Solanumtorvum, Agar disc diffusion method

(c) 2017 The Authors. Published by Innovare Academic Sciences Pvt Ltd. This is an open access article under the CC BY license (http://creativecommons.org/licenses/by/4.0/) DOI: http://dx.doi.org/10.22159/ijcpr.2017v9i3.19982

\section{INTRODUCTION}

Search for naturally occurring materials which are having biologically active substance and show biological activity and in plant chemotherapy, the use of naturally occurring antifungal substances is gaining more importance and have more significant values [1].

Each and every plant contain near about hundreds or thousands of metabolities. Medicinal plants are a wonderful gift of nature and are being used against numerous infectious and harmful diseases in the world since from ancient period of time [2].

It is estimated that $2,50,000$ to $5,00,000$ plants species are there but only a small percentage has been checked phytochemical properties and the fraction submitted to biological screening is even smaller. The plant kingdom has a wide range of population that relies on plant and plant extract for health care [3].

Medicinal plants plays a great role for the health of individuals and communities. It has a huge importance in today's world. These plants have a great medicinal value that lies in some chemical substances which produce physiological action on the human body. Medicinal plants can also be used as food and spices. Medicinal plants contain a multitude of chemical compounds like alkaloids, glycosides, saponins, resins, oleoresins, sesquiterpene, locations and oils (essential and fixed) [4].

Higher plants have the capacity of producing both primary and secondary chemical metabolites, primary chemical metabolites is important in development and reproduction of plants. On the other hand, secondary metabolites acts as defence mechanisms against adverse biotic and abiotic conditions for survival of the plant [5].

The World Health Organization (WHO) told that the best source of obtaining various qualities of the drug is none other than medicinal plants. According to them, about $80 \%$ population of this modern world use traditional medicine, which has compounds derived from medicinal plants [6]. Both plants and plant-based medicaments are the basic needs of the various pharmaceuticals products. The plant kingdom has numerous source of active ingredients which are valuable in the treatment as well as management of different types of disease [7].

Medicinal plants have been tested for various kinds of activities such as antimicrobial, hypoglycemic, antihelmintic, hepatoprotective, antioxidant, analgesic, antipyretic activities, antipyretic, antileishmanial and insecticidal activities [8]. Medicinal plants such as Ocinumgratissimum and Eugenia uniflora are rich in volatile oils. It is also reported that they contain $75 \%$ thymol which has an antimicrobial effect against Staphylococcus sp., Escherichia coli and Shigella sp. They are also used in the treatments like diarrhea human ear infection [9].

The plant kingdom has varieties of plants which are capable of producing secondary metabolites and are used for medicinal purposes for several years [10]. Countries like India relay on such medicinal plants to content against the plant diseases. During seed borne phases the management of fungal pathogens is considered to be a cheap dress disease control strategy [11].

There are many locally available plants and they are rich in source of novel bio-compounds which are cheapest in the source. Isolation, Screening and studying the antimicrobial effect of such biochemical substances is needed to control and treat the diseases [12].

So the target of this present study is to identify the phytochemical components of solanumtorvum and to determine the antimicrobial effects of the dried fruit extract on E. coli, S. aureus, Candida albicans and Trichophytonrubrum.

\section{MATERIALS AND METHODS}

\section{Collection of plant materials}

Solanumtorvum was collected from Deepor Beel Bird Sanctuary, Guwahati India. The plant specimen was authenticated by Dr. G. C. Sarma, Curator, Department of Botany, Gauhati University, Guwahati, Assam. The voucher specimen has been deposited in the Herbarium of the Department of Botany, Gauhati University with voucher no Acc. No-18209 dated 28-10-2016 for future reference. 


\section{Chemicals and reagents}

Ethanol (ET), Petroleum Ether(PE), hydrochloric acid, Dragondorff reagent, Mayer's reagent, Wagner's reagent, Benedict's reagent, sulphuric acid, lead acetate, Molisch's reagent, Fehling solution A and B, sodium citrate, copper sulphate, ferric chloride, sodium hydroxide, glacial acetic acid, benzene, chloroform, ammonia, nitric acid, dimethyl sulfoxide (DMSO), potassium nitrite, gelatine, Beef extract, Peptone and agar. All the chemicals and solvents used were of standard analytical grades.

\section{Preparation of extracts of Solanumtorvum fruits}

The Solanumtorvum fruits were dried under shade and then at tray drier for 370C and undergone crushing in an electric blender to form powdered. Then it was defatted by Petroleum ether and extracted with ethanol using Soxhlet's extractor. The percent yield of ethanolic extract was then calculated out.

\section{Preparation of extract/drug stock solution}

The stock solution of Solanumtorvum seed extract was prepared on each occasion by careful weighing and dissolving in a suitable volume of Dimethyl sulphoxide (DMSO) to get a concentration of 100 $\mathrm{mg} / \mathrm{ml}$. A tablet of ciprofloxacin was dissolved in an appropriate volume of water to get $5 \mathrm{mg} / \mathrm{ml}$ of stock solution.

\section{Phytochemical screening}

Phytochemicals screening were done using standard method. All the experiment has been repeated in triplicate for final confirmation of the result.

1. Test for saponins: To $1 \mathrm{ml}$ of aqueous extract was added to few volume of distilled water in a test tube. The solution was shaken vigorously and observed for a stable persistent froth for $20 \mathrm{~min}$.

2. Test for alkaloids: Two methods were used to test for alkaloids. First, evaporate $20 \mathrm{ml}$ of ethanol extract, the dry residue dissolved in 5 $\mathrm{ml}$ of $\mathrm{HCl}(2 \mathrm{~N})$ and filtered. A few drops of Mayer's reagent and Wagner was added, the presence of precipitate indicates the alkaloids.

Second, 3 to $15 \mathrm{ml}$ of the aqueous extract was added $2 \mathrm{ml}$ of NH4OH à $10 \%$. The alkaloid was extracted 3 times with $10 \mathrm{ml}$ chloroform. The chloroform layer was washed 3 times with $2 \mathrm{ml}$ of HCL (10\%). This was divided into two portions. Mayer's reagent was added to one portion and Wagner's reagent to the other. The formation of a brown or white precipitate was regarded as positive for the presence of alkaloids.

3. Test for sterols and steroids: Extracts were treated with chloroform and filtered. The filtrates were treated with few drops of Conc. Sulphuric acid, shaken and allowed to stand. The appearance of golden yellow colour indicates the presence of triterpene.

4. Test for the phenolic compounds: Flavonoids: The ethanol extract $5 \mathrm{ml}$ was added to a concentrated sulphuric acid (H2SO4) (1 $\mathrm{ml}$ ) and $0.5 \mathrm{~g}$ of $\mathrm{Mg}$. A pink or red coloration that disappears on standing $3 \mathrm{~min}$. indicates the presence of flavonoids.

5. Tannins: Two methods were used to test for tannins. First, about $1 \mathrm{ml}$ of the ethanol extract was added in $2 \mathrm{ml}$ of water in a test tube. 2 to 3 drops of diluted ferric chloride (Fecl3) solution was added and observed for green to blue-green or blue-black coloration. Second, 2 $\mathrm{ml}$ of the aqueous extract was added to $2 \mathrm{ml}$ of water, 1 to 2 drops of diluted ferric chloride (Fecl3) solution were added. A dark green or blue-green coloration indicates the presence of tannins.

6. Test for Glycoside: $2 \mathrm{ml}$ of concentrated $\mathrm{H} 2 \mathrm{SO} 4$ was added carefully and shaken gently. A reddish brown colour indicated the presence of steroidal ring i. an aglycone portion of the glycoside. $[13,14]$

\section{Culture media}

The media employed for the study was solid agar media.

\section{Microbial strains}

Three bacterial strains [Staphyllococcus aureus (ATCC 25923), Escherichia coli (ATCC 25922) and two fungi [Candida albicans (ATCC 10231), and Trichophyton rubrum (ATCC 28188)] were used. Stains were obtained from Girijananda Chowdhury Institute of Pharmaceutical Science, Azara, Guwahati

\section{Sterilization of materials}

The petri dishes and pipettes packed into metal canisters were appropriately sterilized in the hot air oven at $170{ }^{\circ} \mathrm{C}$ for $1 \mathrm{~h}$ at each occasion. A solution of the extract and culture media were autoclaved at $121^{\circ} \mathrm{C}$ for $15 \mathrm{~min}$.

\section{Antibacterial activity}

The antimicrobial activity of the different extracts of the plant was assayed by agar-well diffusion method as described in NCCLS, 1993 [15]. Petri plates containing $20 \mathrm{ml}$ nutrient agar medium was seeded with bacterial strains. Wells of approximately $10 \mathrm{~mm}$ was bored using a well cutter. Plant extracts were prepared in DMSO (stock: 1 $\mathrm{mg} / \mathrm{ml}$ DMSO). The plant extracts of 25,50 , and $100 \mu \mathrm{l}$ concentrations were added. Ciprofloxacin $(20 \mu \mathrm{l})$ and DMSO $(100 \mu \mathrm{l})$ were used as positive and negative controls respectively.

The plates were then incubated at $37^{\circ} \mathrm{C}$ for $24 \mathrm{~h}$. The antimicrobials present in the plant extract are allowed to diffuse out into the medium and interact with the test organisms in the freshly seeded plate. The diameter of the zone of inhibitions was measured in millimetres after $24 \mathrm{~h}$.

\section{Antifungal activity}

The potato dextrose agar plates were prepared and inoculated with a fungal culture. Wells of approximately $10 \mathrm{~mm}$ was bored using a well cutter and samples of different concentration were added. The zone of inhibition was measured in millimetres after overnight incubation and compared with that of standard antifungal (Fluconazole) $(10 \mu \mathrm{l})$ which was used as positive control and DMSO $(10 \%)$ as the negative control [16].

\section{RESULTS}

The present systematic examination shows the phytochemical analysis, antimicrobial activity of the ethanolic extract of the plant solanumtorvum. The yield \% of the extraction of ethanol was $20.28 \%$. It was a dark brown solid powder (ET) in appearance.

Table 1: Phytochemical screening of Ethanolic (ET) extract of dried fruits of Solanumtorvum (family-solanaceae)

\begin{tabular}{llll}
\hline S. No & Phytochemical test & Reagent used (test performed) & Observation \\
\hline 1 & Alkaloids test & Mayer's test & Fesult \\
& & Wagner's test Dragendroff's test & Turbidity obtained \\
3 & Saponin test & Foam test & Golden yellow colour observed \\
4 & Flavonoid test & Lead acetate test & Yellow colour observed \\
& Carbohydrate test & Molisch's test & \\
5 & & Benedict's test & Brownish black ppt not observed \\
6 & Glycoside test & Fehling's test & Ring not formed \\
7 & Steroid test & Modified Borntrager's \\
8 & Proteins and amino acids & Salkowski's test & Reddish black not seen \\
+
\end{tabular}

+sign indicates the presence and-sign indicates absence. 
Table 2: Antimicrobial activity ethanolic (ET) extract of dried fruits of Solanumtorvum (family-solanaceae) using disc diffusion assay

\begin{tabular}{|c|c|c|c|c|}
\hline \multirow[t]{2}{*}{$\begin{array}{l}\text { Name of the compounds and their } \\
\text { concentration }\end{array}$} & \multicolumn{2}{|c|}{$\begin{array}{l}\text { Antibacterial activity diameter of inhibition } \\
\text { zone (mm) }\end{array}$} & \multicolumn{2}{|c|}{$\begin{array}{l}\text { Antifungal activity diameter of inhibition } \\
\text { zone (mm) }\end{array}$} \\
\hline & Staphylococcus aureus & Escherichia coli & C. albicans & Trichophyton rubrum \\
\hline Standard Ciprofloxacin $(20 \mu \mathrm{l})$ & 42 & 40 & ----- & ---- \\
\hline Standard Fluconazole $(20 \mu \mathrm{l})$ & ----- & ----- & 32.21 & 30.01 \\
\hline Plant extract $(25 \mu l)$ & 14.5 & 11.2 & 12.5 & 10 \\
\hline Plant extract $(50 \mu l)$ & 18.33 & 16.51 & 17.3 & 11.2 \\
\hline Plant extract $(100 \mu \mathrm{l})^{*}$ & 20.3 & 18.58 & 21.5 & 16.9 \\
\hline
\end{tabular}

*significant activity

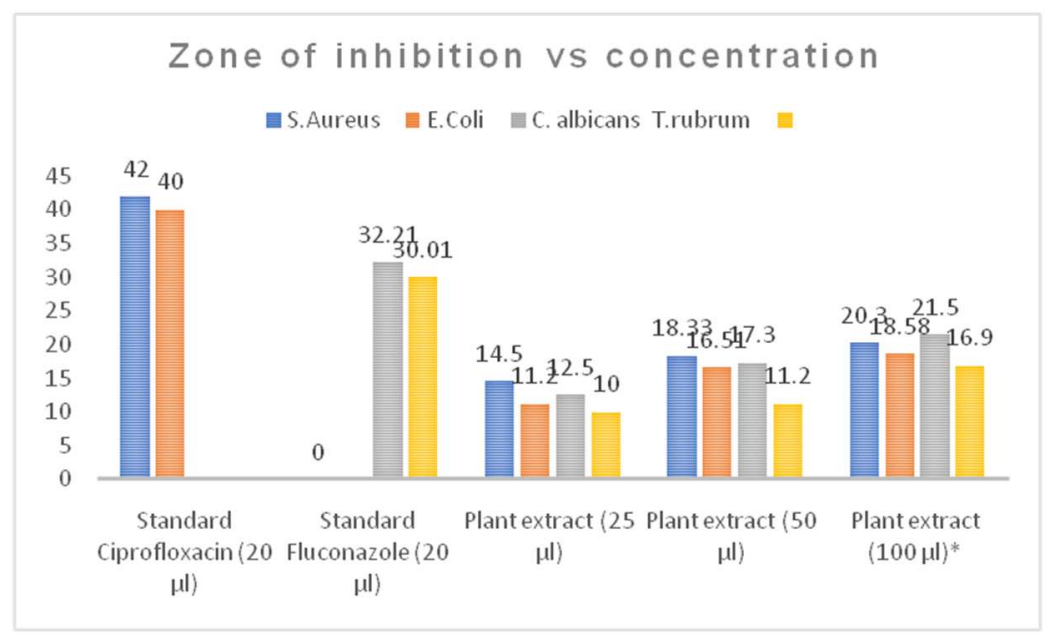

Fig. 1: Zone of inhibition vs concentration

\section{Phytochemical analysis}

The phytochemical analysis with the ethanolic extracts of the dried fruit of plant solanumtorvum showed the presence of alkaloids, saponin, sterols, Steroids, terpenoids, protein and amino acid, tannins, carbohydrate are given in (table 1).

\section{Antimicrobial activity}

Generally, Plant extracts are rich in antimicrobial compounds. The in vitro antimicrobial study of the ethanolic extracts of solanumtorvum under different concentration with the standard are mentioned in (table 2). The ethanolic extracts of dried fruits of the plant solunumtorvum showed antimicrobial activity against most of the test organisms.

\section{DISCUSSION}

Antimicrobial activity of dried fruits of plant solanumtorvum has been evaluated. Phyto-constituents present in plants namely alkaloids, saponin, sterols, terpenoids are having an exciting set of circumstances that makes it possible to do something for more extensive of modern therapies against a wide range of microorganisms. The present study was done against the variety of Gram-positive, Gram-negative bacteria, and fungal strains were selected for screening antimicrobial impact of the extracts to see the antimicrobial spectrum. Results of this study shows that the ethanolic extracts of the plant solanumtorvum were highly successful in producing the desired result against most of the Gram-positive bacteria, Gram-negative bacteria, and fungal strains in agar well diffusion method.

Phytochemical constituents of plants such as tannins, alkaloids, flavonoids, phenolic compounds and several other aromatic compounds are secondary metabolites which can be used in achieving a defence mechanism against plundering by many microorganisms.

The practical exhibition and explanation of antimicrobial activity against both Gram-positive and Gram-negative bacteria and on various fungal strains may be an indication of something presence of broad spectrum antibiotic compounds in the extracts which is shown in fig. 1 . The $100 \mu \mathrm{g} / \mathrm{ml}$ concentration of dried fruit extract of solanumtorvum have an influencing antimicrobial activity.

\section{CONCLUSION}

Medicinal Plant in plant kingdom are the important source of drug and plays a great role for the health of individual and communities. Many plants have been tested for the presence of compounds with therapeutic activity. Therefore, it is absolutely necessary to evaluate the antimicrobial activity of Solanumtorvum.

During the study, the antibacterial activity of the dried fruits of Solanumtorvum was judged by using disk diffusion method. The microorganisms that have been selected for study were Grampositive, $S$. aureus and Gram-negative $E$. coli and fungus like $C$. albicans, and T. rubrum. Study of this micro-organism was done as they are important pathogens and also they have the capacity of rapidly developed antibiotic resistance as antibiotic use increases.

At the end, the study concluded that ethanolic extract of Solanumtorvum showed the presence of various phytochemicals of which include alkaloids, saponin, sterols, Steroids, and terpenoids.

The present study makes us know about the significant antimicrobial activity of the plant extracts when estimated with standards. So, after lots test, decision and thoughts it was found that the minimum inhibitory concentration of the plant extracts was less than $100 \mu \mathrm{g} / \mathrm{ml}$ and therefore the plant was considered to have a very good antimicrobial activity.

However, further studies are definitely required to put light on the unknown biological activities of Solanumtorvum and its effect on living organisms, tissues or cells against various diseases.

\section{CONFLICT OF INTERESTS}

Declare none

\section{REFERENCES}

1. Schmutterer. Properties and potential of natural pesticides from the neem tree. Ann Rev Entomol 1990;35:271-97.

2. Khalil MY, AA Moustafa, NY Naguib. Growth, phenolic compounds and antioxidant activity of some medicinal plants 
grown under organic farming condition. World J Agric Sci 2007;3:451-7.

3. Parekh J, S Chanda. In vitro antifungal activity of methanol extracts of some Indian medicinal plants against pathogenic yeast and moulds. Afr J Biotechnol 2008;7:4349-53.

4. Rajalkshmi G, Ramarendran R, Gomathi N. phytochemical screening and antifungal activity of the medicinal plant. Indian J Pharm Sci 2013;2:8-9.

5. Edriss Amal Elsayed, Alabjar Zuhair Alfadil, Satti Abdalla Abdelrahim. Phytochemical screening of important secondary metabolites in some extracts of two sudanese plants. Glo Adv Res J Environ Sci Toxicol 2012;1:1992-2002.

6. Ellof JN. Which extractant should be used for the screening and isolation of antimicrobial components from plants? J Ethnopharmacol 1998;60:1-6.

7. Shariff ZU. Feeling Nature's PAINS: Natural Products, Natural Product Drugs, and Pan Assay Interference Compounds (PAINS). J Nat Prod 2001;1:79-84.

8. Doughari JH, JS Obidah. In vitro evaluation of the antimicrobial spectrum of Acacia nilotica leaves and bark extracts against pathogens causing otitis infection. Int J Biol 2008;3:111-7.

9. Fadeyi MO, UE Alcapan W. Poor patient compliance reduces the efficacy of metrifonate treatment of Schistosoma haematobium in Somalia. Afr J Pharmacol Drug Res 1989;9:29-30.

10. Arunkumar S, Muthuselvam M. Analysis of phytochemical constituents and antimicrobial activities of Aloe vera L. against clinical pathogens. World J Agric Sci 2009;5:572-6.
11. Shenge KC. Bacterial speek and bacterial spot diseases of tomato in Tanzania, pathogen characterization epidemiology and management options. Ph. D. Thesis, Sokoine University of Agriculture, Morogoro, Tanzania; 2007. p. 271.

12. Tewari SN, Sulka HS, Biswal MK, Nayak. National Academy Science Letters; 1988;11:369-79.

13. Jain P, Singh SK, Sharma HP, Basri F. Phytochemical screening and antifungal activity of semecarpusanacardium 1 . (an anticancer plant). Int J Pharma Sci Res 2014;5:1884-91.

14. Harborne JB. Phytochemical methods. In: Chapman and, Hall. New York; 1984;11:4-5.

15. National Committee for Clinical Laboratory Standards. Performance Standards for Antimicrobial Disk Susceptibility Tests-Fifth Edition: Approved Standard M2-A5. NCCLS, Villanova, PA; 1993a.

16. Kurian S, Josekumar VS. Phytochemical screening, antimicrobial activity and brine shrimp lethality bioassay of different extracts of Alysicarpusvaginalis var. nummularifolius (DC.) MIQ. (family: fabaceae). Int J Pharm Sci 2017;9:1-6.

\section{How to cite this article}

- $\quad$ Lawrence Kalita, Biswajit Dash, Uttam Borah, Juman Deka, Suvakanta Dash. Preliminary phytochemical analysis and antimicrobial activity ethanolic extracts of dried fruits of Solanum torvum (family-solanaceae). Int J Curr Pharm Res 2017;9(3):123-126. 